\title{
THE “HAUSH” PUZZLE: PIECING TOGETHER SUBSISTENCE AND SETTLEMENT AT THE FUEGUIAN SOUTHEAST
}

\author{
José Luis Lanata*
}

\begin{abstract}
LANATA, J.L. The "Haush" puzzle: piecing together subsistence and settlement at the Fueguian southeast. Rev. do Museu de Arqueologia e Etnologia, São Paulo, 6: 11-32, 1996.
\end{abstract}

\begin{abstract}
RESUMO: A ponta sudeste da Ilha grande da Terra do Fogo - Argentina era arqueologicamente quase desconhecida até meados da década de 80 , quando começaram pesquisas sistemáticas. Esta área foi historicamente habitada pelos Haush, um grupo sem um status étnico claro. As diferentes posições sobre eles são resumidas. A informação etnográfica e os dados dos recursos faunísticos - Guanacos (Lama guanicoe), leões marinhos, pássaros e moluscos - são ajustados para postular um modelo de subsistência e assentamento para a área - conhecida como Península Mitre. Ele é aplicado para a localidade arqueológica Rancho Donata, e então é comparado com outros modelos de caçadores-coletores pedestres da Terra do Fogo. Estratégias logísticas para a caça de guanaco parecem ser mais eficientes ao longo do ano. Durante o semstre outono-inverno, a caça de leões marinhos tem lugar dentro dos limites do acampamento - ca. $5 \mathrm{~km}$ da costa. O movimento dos acampamentos de base do semestre primavera-verão parece ser primeiro associado à obtenção de pássaros e peixes e posteriormente à caça de leões marinhos.
\end{abstract}

UNITERMOS: Adaptação a alta latitude - Terra do Fogo - Caçadorescoletores - Exploração de recursos faunísticos - Modelos de subsistência e de assentamento.

\section{The problem}

From the insertion of my archaeological and etnohistorical study of fueguian southeast the lack of coherent previous information on indigenous occupations was clear. As a consequence a research design was elaborated, which considered three alternative propositions concerning indigenous utilization of the area, all of which were to be discussed against the archaeological record (Lanata et al. 1985). According with them the most recent archaeological remains in the area attested:

(*) Departament of Anthropology, University of Buenos Aires and PREP-CONICET. (a) An independent population.

(b) A segment of a larger population, centered in the central Beagle Channel.

(c) A segment of a larger population centered in the steppe, North of the island.

We will synthesize the information that conducted us this proposal.

\section{Denominations and self-denominations}

The first mention of a gentilitial for the area is in Spegazzini (1882: 173), who refers to natives self-named Mäc-ck. Segers, who traveled the North coast of the area by 1886 mentioned the names Loualks - in relation with groups located between 
LANATA, J.L. The "Haush" puzzle: piecing together subsistence and settlement at the Fueguian southeast. Rev. do Museu de Arqueologia e Etnologia, São Paulo, 6: 11-32, 1996.

Policarpo and Buen Suceso - and Kau-keshe and Kospijom for those located north of Policarpo, up to Cape Peñas ${ }^{1}$ (Segers 1891). For Dabbene, Peninsula Mitre ${ }^{2}$ was inhabited by the Manckenkn (1911: 269). Lehman-Nitsche, following E.L. Bridges, named Manekenkn the inhabitants of the Peninsula (1913: 233), while Skottsberg mentioned W. Bridges referring that these people were called 'Hush' (Hos) (1911: 306-307; 1913: 615). Cojazzi, following Tonelli, speaks of the Hauss (1911: 100), Beauvoir mentioned the Haus (1915: 171), and Furlong informs that the Selk'nam - Ona - named Haush to those inhabiting between Policarpo and Sloggett (1915: 434; 1917: 181). By 1931, Gusinde sustained that people living at the Peninsula Mitre - the first to arrive in the island in his opinion were self-named Haus and named Winteka by the Selk'nam - Onas - (1982: 114 and 117). E.L. Bridges considered the existence of four groups in the island, with the Aush in the S.E. tip (1951: 61). Finally, the use of the Haush gentilitial was generalized since Anne Chapman initiated her studies in the area (Chapman 1973a, 1973b, 1977, 1982).

Not all this information is originated in direct sources, and for that reason it should be used with caution. ${ }^{3}$ As an example of the frequent contradictions incurred by different authors, consider Lehman-Nitsche, who reports to have been informed by E.L. Bridges of the selfname Manekenkn (1913: 233), while Bridges himself had subsequently published Aush (1951: 61). On the other hand, Chapman and Hester (1973: 186) follow the specifications of Gusinde (1982: 117), according to whom the selfname is Haush, while Manekenkn should be translated as "tribe companions". Anyway, Chapman herself (1982: 17) mentioned Manekenkn as the authentic denomination accepted by Gusinde, without any supporting quotation. Cooper also concluded that the original name was Manekenkn (1915: 445; 1917: 49).

(1)Lehman-Nitsche (1913: 233) considered that these denominations did not correspond to a gentilitious, but were simply toponym.

(2) Peninsula Mitre is the common name for the fueguian southeast.

(3) It must also be considered that according with some authors, like Holmberg (in Dabbene 1904: 269) and LehmanNitsche (1913: 233), even in the beginning of the XX Century, only a couple of descendants were surviving. On the other hand, personal contact with the inhabitants of Peninsula Mitre was not established by all travellers.
Even when the name they gave themselves, and the name by which they were known to their neighbours is well known, it should be clear to the reader that the problem is not settled. There is support for the existence of what appears to be a discrete human group in the Peninsula Mitre, but their ethnic status is not clear. We are still facing the alternatives delineated above. For that reason, I will use "Haush" just as a shorthand for the inhabitants of the S.E. of the Isla Grande for the period between $1,500 / 1,000$ years BP and the beginning of the $\mathrm{XX}$ Century, but no ethnic consideration is implied.

\section{Geographic limits}

The spatial distribution of the "Haush" is also a source of discrepancy between different authors. Segers localize the "aonas del sur" - including the Loualks, the Kau-keshe and the Kospijom - in the area between Cape Peñas and the Strait of Le Maire, precisely at Buen Suceso (Segers 1891). On the other hand, Cojazzi considers the limits to be Thetis and Fotbey Bays (Cojazzi 1911: 100) (the latter toponym was not found in the available cartography). Gallardo, who talks of the "Onas del este", localize them between Cape San Pablo and Cape San Diego - east of Bahia Thetis - (Gallardo 1910: 291). Furlong successively considers the limits to be between Policarpo River and Sloggett Bay (Furlong 1915: 434), and between Cape San Pablo and Buen Suceso (Furlong 1917: 182). Also Chapman takes San Pablo as the Northern limit, but prefers Sloggett as the southern boundary (Chapman 1982: 17). The more important geographic references are shown in Figure 1.

The question of the precise limits of the "Haush" territory is not an idle matter, since the general region is heterogeneous. Different limits impose habitats for the "Haush" that are ecologically more or less varied. These considerations are important for the assessment of our previously exposed hypothesis.

\section{Sociocultural limits}

Three positions can be discerned concerning the sociocultural status of the "Haush".

(a) They conformed an ethnically independent tribe (Furlong 1915: 434; 1917: 181; Holmberg 1906: 51; Lothrop 1928: 24). 


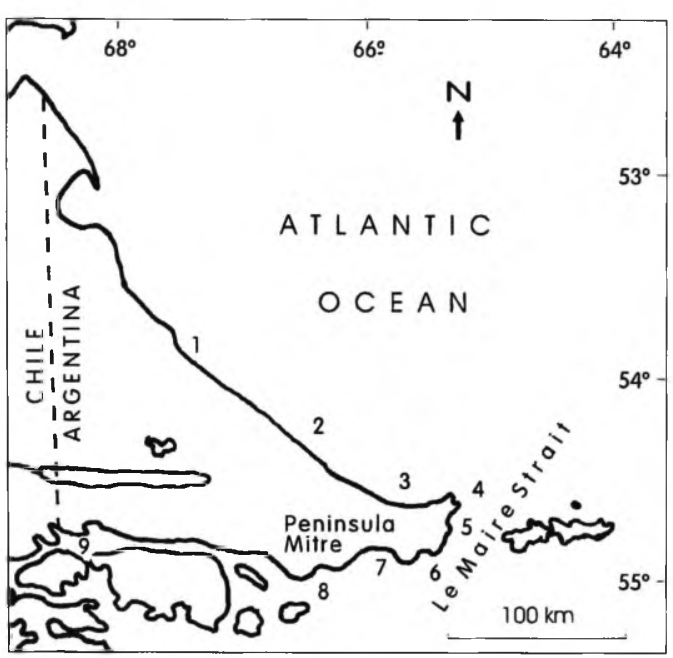

Fig. 1 - Geographic references mentioned in the text. 1: Cabo Peñas, 2: Cabo San Pablo, 3: Bahia Policarpo, 4: Bahia Thetis, 5: Bahia Buen Suceso, 6: Bahia Valentin, 7: Bahia Aguirre, 8: Sloggett, 9: Beagle channel.

(b) They conformed a Selk'nam partiality (Lista 1887: 126; Segers 1891: 77 and 81; Dabbene 1911: 249; Cojazzi 1911: 104; Lehman-Nitsche 1913: 233; Cooper 1917: 52; Gusinde 1982: 118 and 120; Chapman 1982: 17).

(c) They were in a situation intermediate between the Selk'nam and the Yahgan - Yamana-(Cook 1900: 725; Skottsberg 1911: 308, and 1913: 615).

In fact none of the mentioned authors offered unambiguous evidence to sustain they positions. More than that, one observation on which some of these authors agree - a higher dependence on maritime than on terrestrial resources - is given different meaning by Furlong, Segers and Skottsberg.

In general, the characteristics attached to the "Haush" are centered in aspects like their war likeness and hostility against neighbours groups preferentially Selk'nam (Dabbene 1911: 249; Segers 1891: 81; L.E. Bridges 1951: 194; Gusinde 1982: 118; Chapman 1982: 59), ritual peculiarities (Cojazzi 1911: 100), and the already mentioned dietary specialization. From an archaeological point of view, only the latter can be used to construct testable hypothesis, and we will concentrate on them. Anyway, we must not neglect other indicators that may assist in ethnic differentiation, like settlement, subsistence, lithic technology and human osteometric data (Lanata et al. 1985 and 1988).

\section{Environmental and Ethnohistorical data for a "haush" predictive model}

On the basis of ecological as well as ethnohistorical data, a model will be elaborated, to predict seasonal variation in exploitative activities, and a settlement system. Ethnohistorical information will be used to characterize the "Haush" settlement, which appear better defined than that of subsistence. To reconstruct the subsistence system, ecological information will be introduced.

\section{Some considerations on the settlement}

The first mention of the inhabitants of Peninsula Mitre appeared in the Relacion of the Nodal brothers (Nodal 1621). The contact occurred on January 23,1619 , when the Nodals go ashore in Bahia Buen Suceso for the provisioning of water and fuel, and no information concerning dwellings was recorded. On that point, Charles de Brosses (1756, I: 424) inform us that they were fabricated and covered with branches, but no mention is made of the emplacement. ${ }^{4}$

Information given by Father Nyel is also recorded by de Brosses (1756, II: 438). Father Nyel observed, when he was crossing the Strait of Le Maire in the beginnings of the 1704 fall, that the dwellings were constructed with lodges and had an opening on top for the smoke of the hearth. He gave no specification on the emplacement of the dwellings.

The most substantial sources are the Diario de Navegacion and the Noticia Abreviada de los Indios which are concerned with the shipwrecked Purisima Concepcion (January to April 1765) (Purisima Concepcion n.d.). I share Oscar Zanola's opinion that the shipwreckers stayed in the Caleta

(4) It must be noted that de Brosses never visited the area. This compiler of travellers' accounts to the Southern Seas, up to middle XVIII Century, had access to almost all relevant sources. When I was able to compare his transcriptions with the original sources, I noted the excellence of his work. 
Falsa or Bahia Thetis (O. Zanola, pers. comm.). The written sources inform us that while the shipwreckers were looking for appropriate shelter they observed smoke in the forest (Purisima Concepcion n.d.: f. 8), and described huts similar to a half-moon consisting in fixed twigs and intertwined grasses (Purisima Concepcion n.d.:f.19).

Banks and Solander, members of the Captain Cook's expedition, recorded two abandoned huts, one in the forest the other in a meadow, in the Cape San Vicente area at Bahia Thetis. While the expedition was crossing Bahia San Mauricio south of Bahia Thetis -, two aborigines were observed on the beach, whom introduced in the forest when they noted the presence of the ship (Hawkesworth, in Gusinde 1982: 31). When the expedition landed at Bahia Buen Suceso on January 20, 1769, Banks visited the natives in what he refers as their "town", located on "a dry knoll among the trees, which had not been at all cleared, it consisted of no more than twelve or fourteen huts or wigwams" (Banks and Solander, in Gusinde 1982: 33). These huts were conical, and constructed with lodges covered with branches, and have their entrance in the lee side. The entrance was about $1 / 8$ of the perimeter of the base. Parkinson, a member of the expedition, referred that the huts were covered with guanaco and sea lion skins (Parkinson 1784: 8).

Parker King (1839: 448) described one large wigwam and eight men in the NE. corner of Bahia Valentin during May of 1830. Darwin, in 1832 , saw huts constructed with interlocked lodges and covered with branches at Bahia Buen Suceso (Darwin 1958: 183). According with Lista, the natives at Bahia Thetis lived under the humid forest (Lista 1887: 126), while Segers, a member in Lista's expedition, affirmed that they changed huts according with the seasons (Segers 1891: 64). Thus, they might have used the large wigwam constructed with lodges in winter, while in summer they changed to semicircular windbreaks made of branches and guanaco skins and located on the lee side.

$T$. Bridges commented that the eastern and southern 'Onas' that he observed at Bahia Sloggett by the end of the XIX Century, had a guanaco skin shelter, and that their camps were located in the forest (in Gusinde 1982: 45). On the same vein, E.L. Bridges insistently reiterated that the Aush lived in the forest (Bridges 1951: 195-196).
Three characteristics are important within the available ethnohistorical data to define "Haush" settlement.

1) Lack of information concerning the use of the hinterland.

2) Consequently the available information is centered on the coast and its adjacencies. But within that zone some loci are more represented than other; those bays good for landing and for the provisioning of water and fuel, which were so important for sea travelers (i.e., Darwin, Nodal, Banks and Solander, Parkinson, Parker King). In coincidence those loci offered the best settlement choices for the natives, since they concentrate important resources, including a variety of faunal species within their catchments. Precisely in those zones the highest points over sea level for the Peninsula Mitre are reached, and abundant forests of Nothofagus $s p$. are present. The picture is exactly the opposite in the Northern coast of the Peninsula, with the lowest heights and covered with bogs and prairies. Large abrasion platforms, together with the lack of shelter at their beaches, constitute obstacles for landing.

3) Most of the data refers to summer, with the mentioned exception of Father Nyel and Parker King narratives, which correspond to the beginnings of fall.

In sum, a greater part of the reviewed authors coincides in marking the prevalence of huts constructed with branches and/or lodges and covered with grasses and/or guanaco and sea lion skins for the summer. These huts are located on the forest (Purisima Concepcion, Banks and Solander, Parkinson). Some authors are not coincident with the location, but they do in recording summer huts or wigwams (Le hern Brignon, in Brosses 1756, Wilkes 1845, Darwin 1839, 1958) or even in the beginning of Fall (Father Nyel, Parker King). On the other side, diverse authors only briefly mention the selection of a forest habitat for the dwellings (Lista, Th. Bridges, E.L. Bridges).

Segers introduce an observation that can not be ignored. According with him, the dwellings of the 'aonas del sur' change seasonally. In summer a skins windbreak is the prevalescent type of dwelling, while in winter a larger 
wigwam made of lodges and branches replaced the windbreak. The mention of a skins windbreak - recorded in "Haush" zone by Th. Bridges introduce a dimorphism already known for the Selk'nam. Effectively, Cojazzi (1911: 38-41) described for the latter a skins' tent and a pyramidal hut made of branches and earth lumps. The latter is more durable, while the former is well adapted for high mobility. Gusinde also mentions both types of dwellings for the Selk'nam (1982: 177-180).

Two alternative hypotheses are suggested:

1) The "Haush" dwellings changed seasonally, with a more permanent and elaborated type - the wigwam - in winter, and a more simple and transitory type - the windbreak - in summer.

2) The type of dwelling for the "Haush" was more dependent on function than on seasonality. The windbreak was built as a temporary shelter while moving, or perhaps at specific activities' locations; while the wigwam was constructed for multiple activities camps.

Availability of lodges is, of course, an important variable. They are more abundant in the forested zones of the Southern part of the area, thus wigwams are expected to be more important there than in the Northern part of the Peninsula.

In some way, the general information examined above cast doubt on the first hypothesis on dwellings, since a majority of the written sources mention - from Bahia Thetis to the South - the presence of elaborated huts made of lodges, sometimes complemented with skins in summer. In this situation it is necessary to proceed with an analysis of the subsistence patterns in order to develop models of subsistence systems. An approximation to "Haush" subsistence. In this section both the availability of natural resources and the techniques used in order to obtain them will be specified. Ethnohistorical as well as environmental data will be used.

\section{Plants}

Information on the use of vegetal foods by fueguian groups is almost nonexistent, the exception being the studies of Martinez Crovetto $(1968,1978)$. The consumption of plants is mentioned by Nodal (1621: 69), Banks and Solander (in Gusinde 1982:
3), and even in the Diario of the Purisima Concepcion the ingestion of "apios", "berros", "achicorias" and "uvas de corinto" (Berberis buxifolia?) is mentioned.

Clearly only subjective appreciation concerning the real role of plants in the diet can be presented. Thus, while Gallardo marked the importance that they have for the Selk'nam (Gallardo 1910: 178-179), Gusinde gave them a lesser importance (Gusinde 1982: 168-270). On the basis of the species quoted by those two sources, plus the information collected by Martinez Crovetto (1968, 1978) and Moore (1983) Table 1 shows the edible plants, its location in the "Haush" area, and the season when their availability.

The fruits of Berberis buxifolia, Empetrrum rubrum, Pernettya mucronata, Rubus geoides, Ribes magellanicum, etc., were ingested without any type of processing (Gusinde 1982: 270, Gallardo 1910: 178). The fungi (Cyttaria darwinii, C. hookeri) were usually consumed in summer and without preparation; but occasionally women and children collect and put them on a stick where they were allowed to dry by the fire (Gusinde 1982: 270). Gusinde mentioned, for the Selk'nam, the preparation of a powder out of Descurainea canescens seeds, which were later mixed with Sea lion fat (Gusinde 1982: 271, see also Beauvoir 1915: 64, Cojazzi 1911: 61, and Gallardo 1910: 171). Gallardo mentions that in times of hunger the Selk'nam scraped and ate bark soaped in sap from Nothofagus sp. trees (Gallardo 1910: 78).

\section{Birds}

Several ethnographers and travelers mentioned the consumption of birds, as well as the hunting techniques use to obtain them (Lista 1887: 117 and 127, Purisima Concepcion n.d.: folio 21, Segers 1891: 67, Cojazzi 1910: 59 and 100, Gusinde 1982: 262, Gallardo 1910: 169 and 190-193, Beauvoir 1915: 204-205, E.L. Bridges 1951: 332-334).

Some of the consumed species was Chloephaga picta, C. hybrida, C. poliocephala ("gooses"), Anas flavirostris ("Speckled teal"), Anas georgica ("Brown pintail"), Haematopus leucopodus ("Magellanic oystecatcher"), Gallinago gallinago ("Common snipe"), Phalacrocorax albiventer ("King cormorant"). Puffinus griseus ("Shearwater" [Muttonbird]), Spheniscus magellanicus ("Magellanic penguin"), etc. 
LANATA, J.L. The "Haush" puzzle: piecing together subsistence and settlement at the Fueguian southeast. Rev. do Museu de Arqueologia e Etnologia, São Paulo, 6: 11-32, 1996.

TABLE 1

\begin{tabular}{|c|c|c|c|}
\hline \multicolumn{4}{|c|}{ Edible Plants Available in the "Haush" area. } \\
\hline species & Edible part & Location & Availability \\
\hline Apium australe & whole plant & $\begin{array}{l}\text { Southern coast up to Bahia Aguirre, Bahia } \\
\text { Buen suceso, Bahia Thetis, Caleta Falsa } \\
\text { San Pablo Cape }\end{array}$ & Summer \\
\hline Arjona patagonica & tuber & Moat, Bahia Slogget, Bahia Aguirre, & Summer \\
\hline Azorella lycopodioides & rhizome & $\begin{array}{l}\text { Maria Luisa } \\
\text { Southern coast up to Bahia Valentin }\end{array}$ & Summer \\
\hline Azorella selago & rhizome & Southern coast up to Bahia Valentin & Summer \\
\hline Azorella trifurcata & rhizome & Bahia Aguirre, Bahia Valentin, Bahia Buen & Summer \\
\hline Berberis buxifolia & fruit & $\begin{array}{l}\text { Suceso, San Pablo Cape } \\
\text { Bahia Slogget }\end{array}$ & Jan-Feb \\
\hline Berberis empetrifolia & fruit & Bahia Valentin, Bahia Thetis & Jan-Feb \\
\hline Bolax gummifera & rhizome & Bahia Slogget & Summer \\
\hline Hypochoeris incana & root & Caleta Falsa & Yearlong? \\
\hline Hypochoeris radicata & leaves & Bahia Slogget, Maria Luisa & Summer \\
\hline Oreomyrrhys hockery & root & Southern coast up to Bahia Thetis, San Pablo & Yearlong? \\
\hline Pernettya mucronata & fruit & $\begin{array}{l}\text { Cape } \\
\text { Southern coast up to Bahia San Mauricio }\end{array}$ & Summer \\
\hline Pernettya pumila & fruit & Bahia Slogget, Bahia Aguirre, Bahia Thetis, & Summer \\
\hline Ribes magellanicum & fruit & $\begin{array}{l}\text { San Pablo Cape } \\
\text { Southern coast up to Bahia Thetis }\end{array}$ & Summer \\
\hline Rubus geoides & fruit & Bahia Thetis, Moat & Summer \\
\hline $\begin{array}{l}\text { Taraxacum gilliesii } \\
\text { Taraxacum officinale }\end{array}$ & $\begin{array}{l}\text { whole plant } \\
\text { whole plant }\end{array}$ & Bahia Thetis, Moat & $\begin{array}{l}\text { Nov-Dec } \\
\text { Nov-Dec }\end{array}$ \\
\hline
\end{tabular}

The procurement techniques can be classified in four principal types:

a) Hunting in cliffs (for shags): According with Gusinde (1982: 262-266), Beauvoir (1915: 204) and Gallardo (1910: 190) this technique was used at night in the cliffs, where shags nest. Rainy days were preferred since the shags hide the head under the wing. A dead bird was lived in place, and the hunter goes after a new prey. A high number of participants was involved even when the needed tools only are torches and, perhaps, some guanaco or sea lion skin bags for transport. Given that this hunt is at night, a camp near the cliffs is expected, where also some processing of the birds should have taken place.

b) Hunting with sticks: Gallardo (1910: 192) also mention the procurement of birds at lagoons, implying the coordinate labor of some 25-30 individuals of both sexes. They frighten the birds with torches, and kill them with sticks.

c) Use of snares: Apparently this technique was used preferentially by small lagoons with tall grasses. Single or multiple-noose snares were used (Cojazzi 1910: 56, Gallardo 1910: 192, Gusinde 1982: 262-263, Dabbene 1911: 251).

d) Hunting with bow and arrow: This technique was apparently used only by isolated individuals in the forest.

During the summer isolated penguins can be found at the beaches. This is the moulting season, and thus the penguins are defenseless, and it is easy to catch them with bare hands. It must be pointed out that, at least today, there are no penguin colonies in the Isla Grande of Tierra del Fuego.

This review suggests different site types to be expected:

I. Sites located in the proximity of lagoons and/ or nesting cliffs. In those sites the processing 
of the birds is expected - evisceration, separation of the head, parts of low economic value, and feathers - and the length of occupation should be small. They were probably used by a few individuals. Low archaeological visibility should characterize these sites. When techniques a) and b) are concerned, it is expected that the sites were formed in the spring-summer, that is, when availability of prey is higher.

II. Probably no special type of site is formed when technique c) was used, due to a lower number of individuals involved. Quick processing near the snares is expected.

III. A processing site is expected when, technique d) was used, only when an important number of birds was obtained.

Consumption of eggs was probably important. E.L. Bridges mentioned (1951: 52) one event where between 800 and 1600 bird eggs were obtained in the Beagle Channel area. We lack any comparable information for our area, but from the abundant presence of birds (Clark 1986a and b) the collecting of eggs is guessed. Collected by men while hunting, or by specially dedicated women and children, they could have been important in the beginning of spring. As for consumption, there are references both for their eating after cooking (Gallardo 1910: 170), or in the absence of cooking (Cojazzi 1910: 59).

\section{Fish}

Some of the available species in the area are Sprattus fueguensis ("Sprat"), Salilota australis ("Brotola"), Merluccius merluccius ("Southern hake"), Genypterus blacodes ("Southern cod"), Congridae ("Conger") (Bellisio et al. 1979).

Several authors gave fishing an important role within the economic activities of the inhabitants of the southeastern portion of the island (Segers 1891: 66, Purisima Concepcion n.d.: folio 21, Lista 1888: 126, Wilkes 1845: 115, Nodal 1621: 69, Dab-bene 1911: 250, Bridges 1951: 250). Two procurement techniques deserve mention.

The first one is by collecting fishes trapped in intertidal pools, or in the sand with low tide (Purisima Concepcion n.d.: folio 20). This strategy was principally pursued by women and children (ib. f. 21). In the case of intertidal pools a kind of harpoon or hook - or, as indicated by the chronicle of the Purisima Concepcion - a single tendon tied with fodder (ib.). The use of whale barbs is mentioned within the fishing gear (Wilkes 1845: 115). Evidently this technique is dependent on the availability of the resources in specific locations. Our experience suggests that the number of available fish thus obtained was probably low - at least in comparison with the second technique -, but cost of procurement must also has been low.

The second is by fishing with nets made of guanaco tendons (Gusinde 1982: 266, Gallardo 1910: 202). The work was done by men, on the sea or in rivers. The use of nets is indicative of a collective strategy, one presumably producing high quantities of fish. Use of this strategy was probably correlated with the time when shoals are more numerous, a fact surely variable in different species. From an archaeological perspective it is a technique with low visibility, due to the perishable nature of the utilized gear. Anyway, proper analysis of fish assemblages from archaeological sites should alert us about its importance.

\section{Cetaceans}

They constitute, due to the circumstances of their appropriation - scavenging of stranded whales and dolphins - a random but surely used resource (Gallardo 1910: 205). There is no data supporting any seasonality in the stranding process. What certainly is true, is that in rocky coasts the probabilities for stranding diminish (Borrero 1985: 148), and that between 1975 and 1978 it was high the number of stranded cetaceans on the Atlantic coast of Tierra del Fuego $(1975=53,1976=80,1977=$ $94,1978=18$ ), being the most represented species Phocoena dioptrica and Cephalorhyncus commersoni (Goodall 1978).

As already mentioned, stranded whales were more expected in sandy beaches and, as mentioned by Gusinde (1982: 279) and Bridges (1951: 313) they promoted important human aggregations as well as a relaxation of territorial boundaries. Anyway, variable responses were elicited by a stranded whale (see Purisima Concepcion, n.d. and Bridges 1951: 313).

\section{Mollusks}

Mollusks are interpreted in different ways concerning their importance in the diet of fisher-hunter- 
gatherers (i.e. Yesner 1980, Osborn 1977). Consumption of mollusks by the inhabitants of the S.E. of Isla Grande was mentioned by all the travelers that visited the area. We lack information on the techniques used to open the bivalves; only in the Diario of the Purisima Concepcion (nd: f. 20 ) it is mentioned that they were eaten raw, while human groups were moving. It was an activity normally performed by women and children (Gallardo 1910: 203, Gusinde 1982: 268, Purisima Concepcion nd: f. 20) and a flat-eneded stick was used for their extraction from the rocks on the abrasion platform.

The different species present in the area are Mytilus sp., Aulacomya magellanica, Patinigera magellanica, Trophon sp., Nucella sp.. We do not know, on the basis of the written sources, if the natives have any specific preference. From a logistical point of view, mollusks present two important properties: a) high predictibility, and b) they are resources available all year long. Availability of mollusks varied with different types of beach. It is expected that mollusks will be more abundant on those beaches with larger abrasion platforms -i.e., hard beaches like Cape San Pablo, Ea. Maria Luisa, Caleta Falsa, Bahia Thetis - while on sandy beaches they can only be found near the capes delimiting them - i.e., soft beaches like Donata, Duquesa, Luz, Bahia Buen Suceso, Bahia Valentin. The presence of mollusks year long permits its use in times of local low carrying capacity, in spite of its low economic value as measured by its relatively high obtention costs.

It must be noted that the better opportunities for their exploitation are with low tide, when more mollusks area available on the surface, and only transport from the appropriation point to the consumption locus was needed. We ignore if some mollusks may have been transported occasionally without their shells - i.e. when moving camps.

\section{Sea lions}

In collaboration with Alejandro Winograd (Lanata and Winograd 1988) we have elaborated a series of hypotheses concerning the exploitation of sea lions in Tierra del Fuego. They were deduced from an exhaustive analysis of the ethnohistorical record and from the known sea lions behavior, and I will be resumed here. It is expected:
- an increase in the exploitation of sea lions in summer and early fall,

- a natural tendency to obtain different age and sex classes at different moments of the year,

- that if the hunt was performed on land, there is no need of any specialized tool kit,

- a minimal initial dismembering of the prey at the kill site was probably necessary, and

- minimal transport of the prey, with the location of the processing and/or consumption loci within $5 \mathrm{~km}$ from the kill site.

We believe that these hypotheses apply to the case in the SE part of Isla Grande, given that it is a region where a high number of sea lion annual colonies existed before the colonial period (Carrara 1952, Winograd 1986). The first hypothesis is seasonally specific, but the others can be applied to the complete annual cycle.

As for the hunting techniques, I will only consider those operative on land. ${ }^{5}$ The use of clubs is mentioned by Gusinde (1982) and Lista (1887), specially when the prey was intercepted on its way to the water. The use of bow and arrow is mentioned by Cojazzi (1911), Beauvoir (1915) and Gusinde (1982); the latter also describe the throwing of stones. Harpoons are referred by Segers (1891), Gallardo (1910) and others. Gusinde tell us that the "Haush" harpoon - which he calls the "great harpoon" - is similar to those of the Yahgan. According with Lothrop (1928) nets were also used. Verschoot (in Brosses 1756, I: 444) makes reference, in a general description of the natives of Tierra del Fuego, and after visiting Bahia Valentin, of the presence of stone harpoons. An different technique, referred by Segers (1891) is the use of a

(5) We are limiting the discussion to land techniques, because there are only three mentions of canoes for the area. Frezier (1916: 31) mentions two canoes at Bahia Buen Suceso, a fact that he presents as corroborated by the testimony of Monsieur Villemorin, in charge of the Saint Jean Baptiste. A second sighting was by Lefrant (in Segura 1973: 7), and occurred at Bahia Buen Suceso, too. The third is a general observation made by Furlong (1917: 181), who says that the Haush used canoes "in the quieter season of the year". That is all the available evidence, and up to this moment there is no archaeological evidence of canoes. On the other hand, it can not be discarded that Yaghan expeditions occasionally reached the Le Maire area, departing from any place of the Beagle Channel. 
floating decoy - a skin full of grasses -, in which the hunter attract the sea lion with howls and then proceeds to dispatch it with a lodge throwed from a cliff. It may be appreciated that there is no specific tool kit for sea lion hunting, and that some of the mentioned techniques can be the result of random encounters with solitary individuals on the beach.

The different stages in which the sea lion procurement system can be divided is similar to that appropriate for any large sized prey, - kill, butchering, transport and consumption - with a calification. The morphology of the sea lions, almost without meaty extremities that may justify differential butchering, makes the second stage almost unnecessary, except for those very large individuals - males. Being that the case, we may suppose that newborns and females were directly transported to the consumption place, while males were expediently processed near the kill site before transportation.

\section{Guanacos}

The exploitation of the guanaco in Tierra del Fuego was studied by Borrero (1985: 264), specially for the steppe in the North of the island. His proposal of interception hunting is followed here, since we lack any specific information for the area of our concern. ${ }^{6}$ Different situations considered by Borrero are hunting:

a) in paths normally used by the guanacos,

b) in points of broken terrain, using stampedes, and

c) in clearings in the forest. Such interception hunting should have been prevalent in fall, when an intensification of hunting can be defended (Stuart 1977, Borrero 1985).

A generalized opinion concerning the behavior of the guanaco, maintains that it has a marked seasonality in its use of the space, using the coast in winter and the mountains of the interior in summer (Orquera et al. 1977, Stuart 1977). In the particular case of the Peninsula Mitre this model can not be sustained, since significant numbers of guanacos were seen on the coast during summer fieldworks from 1984 to 1990 .

(6) The hunting techniques - specially the ambush - described by Furlong (1912) for the Selk'nam appear to have low credibility.
It appears as safe to base our speculations on the known structure of the guanaco groups. They include: a) familiar groups formed by an adult male, several females, juveniles and newborns, b) male troops, and c) female troops. What is of interest here is that the familiar groups are territorial at least for part of the year. This situation implies a higher predictability. The situation presents itself as interesting for archaeological analysis, but we lack of detailed information on the structure of age classes in local prehistoric sites necessary to infer if the distinct social groups were differentially exploited. The different social groups appear as more difficult to hunt by interception in paths or in forest clearings, than by stampedes. Anyway, the former strategy can not be excluded a priori. A seasonally patterned exploitation can be considered, alternating familiar groups with male and/or female troops. The problem with the latter is that as a target large troops are less predictable; but even considering that situation, it can be suggested that in parturition times - spring - the troops were more exploited than the familiar groups. During the rest of the year - probably with a peak on fall-winter - a greater utilization of familiar groups can be expected. In summer a displacement of interest toward troops, if available at walking distance, may be predicted.

In sum, I postulate an intensive exploitation of familiar groups on fall-winter (see Stuart 1977, Chapman 1977) on guanaco paths or in forest clearings, using an interception strategy, and a strategy centered in troops during spring-summer.

It is a difficult task to discuss these expectations with archaeological materials, since no clear cut age and/or sex groups can be easily tied to any given strategy. The presence of young of less than one year, occurring in fine grained assemblages, should be diagnostic of familiar groups. As for the activities associated with different potential site types, different opinions exist. Bridges (1951: 156257) says that the Selk'nam use to dismember the prey in five units, while Gusinde (1982: 256) maintains that all the processing was done in situ at the kill. We lack any data concerning how the "Haush" butchered the guanaco, but it is probable that hunting camps do not exhaust site variability associated with guanaco hunting. Differential treatments of guanaco bone units conduct to expect different types of sites. Hunting camps should be those comprising a minimum of food remains, 
located in places dominating guanaco territories, generally in low altitude zones (see Stuart 1977). The processing sites should be those represented by bones of lower economical value and with few associated instruments. Parts of higher economical value were probably transported to habitation sites. This site differentiation follows logically from the probable stages of guanaco exploitation process - kill, butchering, transport and consumption. But complicating factors - i.e. direct deboning of meat - may cause the discard of bones of high economical value at processing sites (L.A. Borrero, pers. comm. 1986). We must mention the presence of proximal epiphysis of radio-cubitus and tibia that exhibit cutting marks in sites considered as habitation camps - i.e. sites at Ea. Maria Luisa and Cabo San Pablo (Borrero and Lanata 1988). It is possible to think that, together with the absence of diaphysis, this presence may mean that while butchering those bones were cut down the proximal epiphysis, and transported as riders with choice parts - humerus, femurs - to habitation sites. Consumption of meat off habitation sites may also complicate interpretation of faunal assemblages.

\section{An annual strategies model}

Before presenting our predictive model of differential resources exploitation in an annual cycle for the "Haush", we will comment on certain general properties of the study area, that must have gravitated in the process of human adaptation. First, it is a region of small size - with an approximately triangular shape, and a surface of about $3,500 \mathrm{~km}^{2}$ - , and a few days are needed to travel it by foot. Second, the inhabitable part of that region is still smaller, given the number of mountains, dense forests and bogs. Thus, the coastal zone is possess a higher biomass than the interior, where the unique available resource appears to be the guanaco. Finally, even when the rigors of the fall-winter semester are more marked - low temperatures, snow falling -, the spring and summer are also harsh - strong winds from the south and west, low temperatures. There are marked differences in the length of diurnal light, with ca. 17 hours in summer and ca. 7 hours in winter, given the high latitude $\left(54^{\circ} \mathrm{S}\right)$. These properties are sufficient support for Chapman and Hester's claim that marked seasonal di- morphism in settlement patterns is not to be expected (Chapman and Hester 1973).

\section{Fall-Winter semester}

This semester is characterized by sea lion exploitation in fall, together with a better utilization of the guanaco family groups. Considering that there are no abundant exploitable vegetal resources specifically fruits -, the availability of fish diminished, and some birds migrate, it should have been important to locate the base camp next to the sea lion rookeries and/or guanaco territories. Two factors converge on this: a) control of both critical resources in the most difficult part of the year, and b) maximize utilization of the available light hours.

It is possible to assume camps located in areas dominating both rookeries and guanaco territories. Such places can be found in parts were forests are not too dense. From those advantage points, both resources may be controlled with few movements, and return to camp with diurnal light, saving energy in a semester characterized by a low availability of resources. Given the information presented above, in fall it may have been useful to locate the camp first nearer to the rookeries, and then to transport it to the vicinity of guanaco family group territories, or eventually to places where male and female troops were located. Another alternative was that within the $5 \mathrm{~km}$ proposed for the sea lions exploitation, potential guanaco hunting stands were available. The latter situation should not require subsequent transport of the camp. This second alternative allows members of the camp easy access to secondary resources: the fishing and/or gathering of fishes at intertidal pools, or the hunting of birds with bow and arrow at the forest. Other bird species, that in this season are concentrated in lagoons and other low zones, can be hunted with different techniques.

In sum, I postulate for the fall-winter semester a settlement where base camps are placed within areas located no more than $5 \mathrm{~km}$ away from the rookeries - seasonal or annual - and which also had a reduced catchment, including spaces occupied by guanacos. Those camps do not have to be necessary located on the coast. Better conditions are offered by the limit of the forest, where there is better wind protection, and the fuel supply - important for war$\mathrm{mth}$ and light - is more or less constant. Functionally specific sites are a possibility in this semester, and it appears as plausible that such sites may be 
identified by the general structure of the deposited faunal remains. We think that we must explore differential faunal structures as seasonal indicators, so as to base our seasonal hypothesis on wider evidence than that offered by annular rings on fish vertebrae.

\section{Spring-Summer semester}

During the spring the behavior of guanacos familiar groups or male and female troops - is more hostile, since it is mating period, and accordingly a time when the males fight for the access to females. This puts the individuals in an unusual state of alert. Competence between males is frequently violent, and at this time of the year some kind of division of male troops operates, specially the young that leave the troop to look for females. These behaviors make it difficult the hunt of familiar groups, except perhaps when males are fighting, which may be the occasion to stalk defenseless females. Another potential prey are adults that do not compete for females, and which maintain themselves far away from the familiar groups. Also wounded animals resulting from male fighting may become useful targets on certain cases, those of severe injuries.

It is possible that sites formed in this time of the year had peculiar faunal assemblages, resulting from the differential availability of guanaco age groups. The strategy should have been one of intercepting isolated or defenseless animals. The postulated events are difficult to identify archaeologically. It is also expected that the potential hunting grounds were incremented due to the division of the guanaco troops, and also to thawing of the ground that makes available more space for the distribution of animals.

Parturitions occurred during summer, and thus the protection of guanaco territories is more marked. This should make it more difficult to hunt individuals, except for newborns that were left behind. For that reason we expect male and female troops to be a better target in this season, since once the fighting period was over and some social turnover had operated, troop members continue with their normal non-territorial pattern. The logistically organized hunt of those groups appears as a probable strategy.

A similar situation occurs with sea lions, since copulation and parturition occur in this semester.
The human exploitation area is maintained constant due to the precise situation of the annual or seasonal colonies. Anyway, the annual colonies appear as year round resource, and perhaps a specially used one from the end of summer until the end of winter (Lanata and Winograd 1988), which is not the case with the seasonal colonies, which exploitation is better at the end of the summer. As a result, I postulate that in spring females standing away from fighting males, and wounded males resting on the beaches, are selectively pursued. Newborns and females appear as the more plausible prey in summer. In sum, particular sea lion bone assemblages are expected for spring and summer.

Most of the edible plants are exploitable in this seasons. Their availability is different if they are roots, leafs or fruits are involved. The fruits are apt to be eaten in the beginning of summer, while leaves and roots can be already eaten in spring. I am cautious concerning the consumption of plants, given the lack any quantified data. I believe that it was a resource which occupied an important place in the diet, albeit a lesser one when compared with meat obtained by hunting. Its use must have been restricted to the moments of higher availability, or as a random resource during starvation periods or while traveling.

Migratory birds begin to arrive in the island in spring, and thus the number of available resources increases notably. Also the nesting period began, which gives place to the gathering of eggs. We have already mentioned that eggs have low appropriation costs, high predictability and high daily returns. The best exploitation places should be in the interior lagoons, in capes and, in general, by the sea coast - where most colonies are located. Thus, base camps used in these seasons should include a high variety of bird remains.

When the beginning of spring spawning time arrives, and numerous schools of fish are going near the coast. So, the river mouths, due to nutrients they carry, can be considered as areas were fish shoals concentrate. Any of the mentioned techniques could have contributed a high number of individuals, specially the net technique.

On spring the settlement could have been located according with the availability of birds and fish. These are coastal locations closer to river mouths. A base camp on that location should permit a tight control of nets for fish, as well as of stranded animals. Specific activity sites, like guanaco hunting 
LANATA, J.L. The "Haush" puzzle: piecing together subsistence and settlement at the Fueguian southeast. Rev. do Museu de Arqueologia e Etnologia, São Paulo, 6: 11-32, 1996.

stands, should have been located far away from the base camps. Since this is a time when male and female troops are behaviorally available, and it is not easy to predict their location, a need arose to move to find the prey. Hunting stands could also be located in relation with the location of familiar groups, where male fighting facilitated the female or wounded animals' procurement. Guanaco's procurement could be as much resulting from a logistical strategy - male and female troops, and familiar groups -, as by encounter of isolated-solitary males - or defenseless individuals - females, wounded animals. Thus, a widening of the hunting grounds is expected, including piedmont zones where the snows are beginning to melt.

The spring is not appropriate for the exploitation of sea lions, but beach scavenging as well as isolated hunting episodes at the rookeries may have been implemented from the base camp.

Plant gathering should be focused on certain high availability places, principally in parklands (Bondel 1985) and marginal forests. These zones may have been visited in procurement of these resources. Random gathering should also be considered.

\section{The Rancho Donata case}

Information from Rancho Donata, an archaeological locality located on the north coast of the Peninsula Mitre at $65^{\circ} 54^{\prime} \mathrm{S}$. and $54^{\circ} 66^{\circ} \mathrm{W}$. (Figure 2 ), will be introduced. The locality was first visited by Anne Chapman (Chapman and Hester 1973) and I preformed fieldworks in 1984, 1986 and 1988 (see Lanata 1995).

Rancho Donata is basically a beach of some $1,6 \mathrm{~km}$ long, at whose eastern extreme the Policarpo river meets the ocean, forming a notable marsh. This river marks the southern limit of the zone with wide beaches with ample and gentle half-moon bays limited by a rocky cape in Peninsula Mitre. It has large bogs and low-altitude steppe prairies patched with Nothofagus forests in the hinterland. The Andes Mountains are located at the south, conforming a very different landscape. ${ }^{7}$ It must be

(7) Starting in the Policarpo River to the South, the coast is of irregular shape, and present 15 to $20 \mathrm{~m}$ height cliffs. The bays and coves in that zone display particular characteristics that render them different from those to the North. remembered that for some authors the Policarpo river is the limit for the distribution of the "Haush" (i.e. Furlong 1915: 434).

\section{Resource availability at Rancho Donata}

I will evaluate the different resource types available in the area. This data was obtained during summer fieldworks, and for this reason discussion has to be limited to this season.

Clark (1986a) completed a bird census - see Table 2. Unfortunately this census was done in February, and thus is almost null the information on eggs, which should be available in the area at least since November. As indicated in Table 2 most of the birds are located principally near the mouth of the Policarpo river, by the Donata lagoon, and at the north of Punta Loberia.

Merino studied the distribution and structure of guanaco groups. Several formations were recorded in 1986 and 1988 (Merino 1988): one familiar group (1 male, 2 females and 1 young) near the Donata lagoon, one male troop (14 individuals) in the area between Cerro Mesa and Playa del Duquesa, one male troop ( 15 individuals) in the forested area of the river, one solitary male on the beach near the concentration of archaeological sites, and three solitary males between the small streams and the mouth of the river.

Winograd studied the Otaria flavescens (Southern sea lion) colony located at Punta Loberia (Winograd 1986). A census made in february 1984 counted 287 individuals, including 246 females, 16 males and 25 pups. It must be mentioned that in 1986 the number of individuals diminished (A. Winograd, pers. comm.), while Carrara (1952) mentioned for that rookery a total of 4875 individuals. Carrara refer to another Otaria flavescens colony located to the east of the Policarpo river, including about 2600 individuals. It appears as pertinent to recall Carrara's data, which is indicating a notable diminution in the number of individuals since 1950 - probable causes are mentioned in $\mathrm{Wi}$ nograd 1986.

We lack any specific data on the availability of fish in the area, except for the presence of the already mentioned species.

The plant resources locally available are relatively few. Berberis $s p$. fruits are available on the east flanks of the Cerro Mesa and Monte Arriola, as well as isolated Apium australis near the mouth 


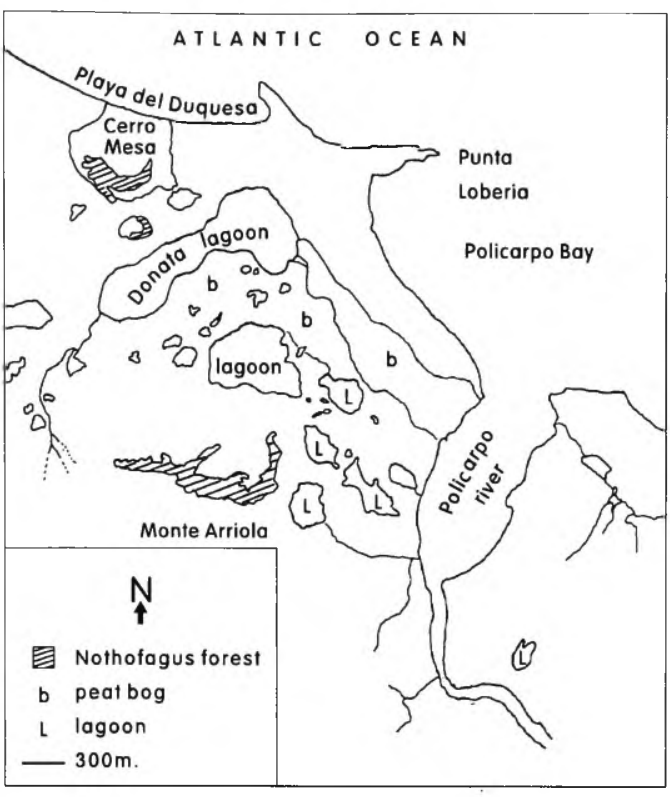

Fig. 2 - The Rancho Donata archaeological locality.

of the Policarpo river. Rushes useful for the construction of baskets are available in the mouth of the small stream draining into the Donata lagoon.

\section{TABLE 2}

Bird Census At the Rancho Donata Area from Clark (1986a).

\begin{tabular}{llc}
\hline \multicolumn{1}{c}{ Species } & \multicolumn{1}{c}{ Zone } & Quantity \\
\hline Phalacrocorax albiventer & Punta Loberia & \pm 160 \\
Puffinus griseus & Punta Loberia & $\pm 5,000$ \\
Chloephaga hybrida & Luz river & 59 \\
& Punta Loberia & 57 \\
& Policarpo river & 30 \\
Chloephaga picta & Policarpo river & 94 \\
& Donata lagoon & 62 \\
Chloephaga poliocephala & Donata lagoon & 8 \\
Anas flavirostris & Policarpo river & 20 \\
Anas georgica & Policarpo river & 20 \\
Haematopus leucopodus & Policarpo river & 107 \\
Gallinago gallinago & Policarpo river & 30 \\
Leucophaeus scoresbii & Punta Loberia & 12 \\
Larus dominicanus & Policarpo river & 120 \\
Aptenodytes patagonica & Policarpo river & 1 \\
Pygosealis antarctica & Policarpo river & 1 \\
\hline
\end{tabular}

The study of the intertidal area at the beach in Donata was performed by Sandra Gomez de Saravia (1986), and offered the following preliminary results. The mesolittoral section was divided in three sectors, the inferior dominated by Aulacomya magellanica, followed by Patinigera magellanica and Trophon sp. with low presence of Mytilus chilensis. The medium sectors present an increase in Mytilus and a diminution in Aulacomya, with low representation of Nucella sp. The superior sector is dominated by Aulacomya, associated with a marked increase of Mytilus, and low representation of Patinigera. The supralittoral section is characterized by a codominium of Mytilus and Aulacomya, with rare Patinigera and Trophon. All these species correspond to a rocky substratum, the only one presented at the cape in Punta Loberia. In comparison with other beaches in the Peninsula Mitre - i.e. Caleta Falsa, Bahia Thetis - the availability of mollusks at Donata is very low.

The soft sandy beaches are adequate for the stranding of whales. In this case the beach has a length of $1.2 \mathrm{~km}$, and the tidal wide discovers almost $400-500 \mathrm{~m}$ of beaches, thus facilitating the process of stranding. In fact, the bones of different species of cetaceans are widespread on these beaches.

Studies by Hugo Nami $(1986,1992)$ at the lithic workshop located close to Punta Loberia (see Chapman and Hester 1973) indicated that the beach cobbles used as cores were obtained at the western end of the Playa del Duquesa, some $4.8 \mathrm{~km}$ from the site (Nami pers. comm.). There are no cobbles at Playa Donata itself. A concentration of thermal treated cobbles observed at the site may have come from the same source.

\section{Spring and summer catchment of Rancho Donata}

The presented data may be used to sustain that the Policarpo Bay has a sufficient variety of summer resources for fisher-hunter-gatherers within a $5 \mathrm{~km}$ radius from the central portion of the beach. It is possible to think on a staged use of these resources, according with the most adequate timing for their exploitation. Intense use of birds and fish may be postulated for spring. The mouth of the Policarpo river appears as appropriate, since nets may be used there taking advantage of tides. Being the spawning season, the number of stranded fish increased. So- 
me places near Punta Loberia appear as appropriate for the procurement of birds on the cliffs, while near the river the use of snares should be more adequate.

In this semester it is necessary to search for the male and/or female troops, which are more obtainable than other guanaco social groups. Guanaco hunting grounds may be postulated at Cerro Mesa, Monte Arriola, or perhaps in mounts located in the interior. Processing sites may have been located on low flanks.

By the end of summer the exploitation of the sea lion colonies must have been emphasized, but isolated individuals should have been available since the beginning of the season. The rookery may be approached from the top of the cape or, waiting for low tide, from the beach. The latter is the indicated way out of the rookery when it is needed to transport the prey. On the lower parts of the cape some processing could took place. Stranded whales and mollusks are not considered here, since the former are fortuitous resources and the latter are not well represented today in order to discuss differential availability.

Two alternative spring-summer settlement systems are presented. In one the location of the base camp is changed as a function of staging in the appropriation of resources. In the other, only two camps are used along the semester. In both cases limited activities' camps are also necessary.

There are other factors - besides location and availability of food resources - that are important for the location of camps, such as fuel, water and shelter from the wind. Today fresh water sources are situated on the east of the bay, or in the interior lagoons. What seems to be an old drainage of the Donata lagoon was detected running parallel to the cape Punta Loberia. Fuel can be obtained from materials accumulated by the sea on the beaches, or from the forests on mounts Mesa and Arriola, which also are offering protection from the winds. Anyway, having in mind that the potentially exploited food resources are within a reduced catchment, we think that the location of a base camp will privilege access to them, even when that means the economically costly operations are needed for the provisioning of fuel and water and protection from the wind. Such a place should not disturb guanacos or birds. The sea lions offered no such problem, since their home range is aquatic.
The concentration of the archaeological sites is in the central zone of the beach, not far away from the high tide line. According with the factors just reviewed, this zone, together with the plains next to cape Punta Loberia, includes the more adequate places for a base camp. Limited activities camps may have been located in different areas. Bird hunting sites should have been placed at the mouth of the Policarpo river, and nearby the Donata lagoon and Punta Loberia. At Punta Loberia, where today a shag colony is located, we can postulate hunting on the cliffs. Sites near the cape should be expected, probably with evidences of bird processing. Such sites should be characterized by the disproportionate presence of low economical value bones - from the head, cervical vertebrae, tibiatarsals. At the mouth of the Policarpo river, as well as in the Donata lagoon, bird processing derived from snaring should have a lower archaeological visibility in comparison with the previous case, except in the case of redundant use of the same locus. In that case one may get the wrong impression that the use of a more intensive, collective technique, may explain the accumulation of bird bones.

The mouth of the Policarpo river and the sea coast are the appropriate places to look for fish. Unusual frequencies of caudal vertebrae and head bones may characterize fishing sites, specially considering the size of some of the available fish.

If the occupation was during spring-summer we can postulate that practically all bone units should be represented at those sites, with a high female/male ratio, and a high percentage of newborns. Having in mind the marked sexual dimorphism of the sea lions, perhaps some processing of adult males may have taken place near Punta Loberia.

High altitude loci with a dominance of the space between Cerro Mesa and Monte Arriola may be considered good guanaco hunting ground for female and/or male troops. Processing sites may be located in the lower flanks of those mounts, by the forest limit.

The proposed settlement differs, as emphasized previously, in the presence of a mobile base camp or its lack, as a function of differential preservation of resources. Anyway, since the appropriation area for most of the resources - birds, fish, sea lions, mollusks and eventually whales is found circumscribed to a radius of $5 \mathrm{~km}$ from 
the central part of the beach, we propose a relatively stable base camp, with guanaco hunting stands located at more than a day's walk. According with what was previously said, a settlement system that locate its spring base camp near the mouth of the Policarpo river is postulated. Its location in summer is in the NW. extreme of the bay, to control the local rookery.

\section{Some considerations}

In the general predictive model of resource exploitation, as well as in the specific model for the occupation of Rancho Donata, different behavior patterns are expected to justify the use of functionally specific types of sites, besides base camps. Types of sites may be enumerated: 1) logistical, 2) home range, and 3) incidental. ${ }^{8}$

Logistical sites are those which are produced within a logistical radius, as a result of specific activities developed at overnight camps away from the base camp (Binford 1982: 7). Home range sites are those produced by the group within the action range of the base camp, and do not imply the installation of a camp. Incidental sites are those which are the product of specific activities that were not programmed, and accordingly may be located indistinctly within the camp range or the annual range. The definition of incidental sites is undoubtedly ethnographically charged, and appear almost impossible to differentiate archaeologically from other types. Its characteristics are absolutely opposite those of a logistical type. I understand that logistically organized activities presuppose a plan -i.e. a guanaco hunting party. Incidental sites, on the other hand, result from the unexpected, like random encounters with animals - a stranded sea mammal on the beach, the processing of wounded guanacos, or the random gathering of eggs and plants.

Logistical sites should be more related with the hunting of guanacos, or birds in the cliffs. The latter case is interesting, since technically speaking those sites should be located within the

(8) Even when this site type may be named 'transient', we prefer to use the name 'incidental', referring to those events that were not planned (i.e., random hunting). On the other side, the term 'transient' implies a plan. home range, but due to the use of nocturnal strategies, the formation of a logistical camp is expected within the home range in certain cases: as I said, most of the specific activities' sites proposed here are located within a range of $5 \mathrm{~km}$. Then, the pattern of spring-summer space use may be characterized as that of complete radius (Binford 1982: 9), with the peculiarity that half of the space is in the ocean, since the base camps are located near the beach. For the fall-winter semester, with a base camp near the forest, the space use pattern should be more adequately termed of complete radius. This characterization differs from Borrero's model of high residential mobility for the Selk'nam (Borrero 1985: 300). In the Rancho Donata case the high mobility is restricted to the home range. The strategy then, is one of patterned mobility within the home range, with limited logistical movements for the hunt of guanacos and shags.

It is clear that reality should have been more complicated than exposed by this model. I expect that the complete study of the materials obtained in Rancho Donata will suffice to refute it.

\section{The archaeological evidence}

I will not present a detailed list of the archaeological findings at Rancho Donata (see Lanata 1986, 1990, 1993, 1995), but will mention some property of the samples. Most of the concentrations of archaeological materials are in surface and located in the central portion of the beach, at a distance of 50-100 meters from the high tide line. Identified sites are varied; large shell middens - i.e. RD 3: $72 \mathrm{~m}^{2}$, RD7= $560 \mathrm{~m}^{2}$, RD10: $800 \mathrm{~m}^{2}$-, concentrations of thermal treated cobbles with a few instruments and without any traces of food remains, concentrations of cetacean and sea lion bones with few instruments, sites formed with the remains of shipwrecks and associated with glass workshops. A large lithic workshop was found at the interior side of the Punta Loberia cape, at an advantage point for the observation of the hunting grounds. This location justifies transport of the cores, which were prepared with cobbles from the Playa del Duquesa - $5 \mathrm{~km}$ to the West. Two stratified sites were found in the eastern sector of the Playa del Duquesa, near the workshop. Sites containing mollusks and 
guanaco bones are found at the top of Cerro Mesa, and there are also evidences of human occupations at their lower and forested flanks.

Preliminary results at Rancho Donata locality show that the concentrations of archaeological materials appear at locations predicted for spring-summer base camps. The systematic sampling design used in that area permit us to observe the existence of endscrapers, arrow points, large projectile points - tips and tangles - , and side scrapers. Bone remains at the larger sites (RD 5, 7 and 10) indicate an important presence of birds and fish, ${ }^{9}$ as well as guanaco and sea lion newborns (Lanata 1993), implying its use in spring-summer, at least. The presence of large projectile points - 10 to $12 \mathrm{~cm}$ long with expanded tangles, was also detected. They may have been used as harpoons (see de Brosses 1756, I: 444) (Ratto 1991). This may help to explain the low representation of bone harpoons. Abundance of whale bones in sites and near vicinity - vertebrae, skulls, ribs; some with cut marks - suggest cetaceans scavenging.

Data from Rancho Donata permit to confirm some of our predictions. Continuation of the excavations, as well as in deep studies on the recovered materials will permit re-examination of the model. In a more general perspective, recent anthropometric data shows some affinities Selk'nam"Haush", but it do not constitute an authentic proof of identity (Guichon 1993 and pers. comm.). Even when the studies of lithic materials from different Peninsula Mitre sites (Nami 1986, 1992 and pers. comm; Ratto 1991 and 1993) do show some peculiar characteristics, like beveled points and retouches, large points with expanded tangles presumably used as harpoon heads -, thick endscrapers; there are also arrow points and harpoons (Casiraghi 1986) which are comparable to those of the Selk'nam.

\section{Other Fueguian models}

The subsistence and settlement models available for Tierra del Fuego are those of Stuart (1977), Moore (1980) and Borrero (1985) for the Selk'nam area, and of Jackson and Popper (1980) and Stuart (1983) for the Yahgan area. Stuart and Moore settlement models postulated an alternate use of the coast and the interior, spending summer and winter in the coast, and fall and spring in the interior. On the other hand, Borrero proposed a more complex situation, with factors other than seasonality to account for the use of any given habitat (Borrero 1985: 276-277).

Jackson and Popper visualize the Yahgan settlement as concentrated near the coast in winter and spring, and on the coast in summer and fall. Stuart's model for the Yahgan is dependent on the use of canoes. These Yahgan models will not be explored here.

The model presented here differs from any of those mentioned, since we postulate that base camps were never located more than $5 \mathrm{~km}$ from the coast. In that sense I may concur with Borrero (1985: 315) when he talks of lack of specific seasonal differentiation in the Selk'nam adaptation. As for site typologies previously presented, those of Stuart and Borrero for the Selk'nam are the more useful. The typology presented by Moore is too general, and for that reason is not adequate for my purposes. Site types presented by Stuart (1977: 276-281) are based on ethnographic information, while the elaboration presented by Borrero (1985: 230 ), is archaeologically defined. Anyway, I am not to consider it any more, since it is not appropriate for the "Haush" area.

Specialized site types proposed by Stuart are basically related with the hunting of the guanacoFall guanaco hunting lodge camp, Guanaco hunting base camp, and Guanaco hunting camp. They share some properties with mines - their location at high places or in the forest - and differ in that they are seasonally used and in the lack of redundancy in the occupation. At first sight Stuart's three categories appear as similar to the hunting stands that I proposed, but they are not. Stuart's first two categories coincide with my base camps. Stuart's Guanaco hunting camp is equivalent to my 'guanaco hunting stand', which is a place located to control spaces used by guanacos. Those stands could be located far away from the base camp, and can be defined as small sites (Borrero 1986). I think that Stuart's Fall guanaco hunting lodge camps may be more related with the hunting of familiar

(9)The excavation of RD A-310 presented ca. 400 fish vertebrae in one square $\left(1 \mathrm{~m}^{2}\right)$, with à vertical dispersion of only $2 \mathrm{~cm}$. This remains are now under study to determine the season of death. In that square the dominant bones are those from birds and fish. 
groups, due to seasonality and redundancy in the occupation (Stuart 1977: 277). On the other hand, their Guanaco hunting base camp, and Guanaco hunting camp may be related to the hunting of male and/or female troops, since they are camps not used every year.

Another specialized site type in Stuart's typology is his Spring Sealing Base Camp (Stuart 1977: 278-279), which differs from what we proposed, since we consider that sea lion exploitative activities took place from the summer on, and we contemplate the addition of other alternative coastal resources. My generalized base camp was proposed on these bases. In a way it may be compared with Stuart's Generalized Littoral Resource Camp (1977: 279), even when he considers that this type of site may have also been used in winter and we only attribute it to summer use. Other generalized camps proposed by Stuart (1977: 280) are located in the forest and are used in midwinter and midsummer; the former are equivalent to our winter base camp. Being almost nil the evidence for the use of Kloketen camps in the Peninsula Mitre, we do not count that type in our typology. On the other hand, a number of specific activity sites - exploitation of birds, fish, plants - are added in our model.

The major difference between our model and Stuart's is, perhaps, the difference in subsistence. While Stuart's model is heavily inclined to emphasize the exploitation of the guanaco over sea lions, both resources are critical in our model. For the time being we lack of any quantification of the importance of guanacos and sea lions within the Isla Grande different populations, but we feel that sea lions must have an important place within the human diet as sources of lipids. On the other hand, our model gives importance to birds, fish, and plants (Lanata 1986, 1990, 1993, Savanti 1994, Vidal 1985).

In sum, I think that Stuart's ethnographic model, even when sharing a number of properties with our model, could be more useful in marking changes within Selk'nam strategies once they were in fluid contact with white colonists. This change, occurring since the end of the last Century, was already considered by Borrero (1985 and 1991). In opposition, my general model is trying to include what I consider a logical chain in the exploitation of resources (see also Muñoz 1994). Of course, this model is to be refuted with our own work and with that of Vidal at the Southern littoral of the Peninsula Mitre (Vidal 1985, 1986, 1987, 1988).

\section{Summary and conclusions}

A predictive model was presented, as well as the archaeological case of Rancho Donata in what is considered the "Haush" area. My proposal is that Peninsula Mitre human populations possess two critical resources - guanacos and sea lions and used an important biomass of birds and fish. The latter serve as an alternative resource, which helps not to overexploit large mammals stocks. The strategies appear to have been different in fallwinter and spring-summer. Logistical movements for guanaco hunting were favored in fall-winter, while hunting of sea lions occurred within the camp range. Base camps were located in the limit of the forest, within $5 \mathrm{~km}$ from the coast or, strictly speaking, from a rookery. In opposition, the strategy during spring-summer is one of patterned movements locating base camps mainly on the coast in relation with different resources - initially birds, then fish, and finally sea lions. Guanaco male and/ or female troops were searched with a logistical strategy.

This model is confirming some observations from ethnohistorical sources concerning increased utilization of littoral resources in the "Haush" area in relation with the Selk'nam area. Recent stable isotopes analysis from human bones of the whole Tierra del Fuego, shows that diet in Peninsula Mitre samples was important in maritime resources, more than the Selk'nam but less than the Yahgan (Yesner et al. 1991). Anyway, we are far from a position from which to choose on any of the three hypotheses on the attribution of the Peninsula Mitre's archaeological record. In a few years the results of different projects in progress will throw new light on this problem.

\section{Acknowledgments}

I want to acknowledge Oscar Pablo Zanola, from the Museo del Fin del Mundo, Ushuaia, who together with Beto Brizuela and Luis Sosa relied on me for the direction of the "North of Peninsula Mitre Archaeological Project" and who helped me in any conceivable way. To Hugo Nami and Ricardo Guichon for his acceptance to work together in that project. To Ricardo Clark, Carlos di Filippo, Sandra Gomez de Saravia, Mariano 
LANATA, J.L. The "Haush" puzzle: piecing together subsistence and settlement at the Fueguian southeast. Rev. do Museu de Arqueologia e Etnologia, São Paulo, 6: 11-32, 1996.

Merino, Hernan Vidal and Alejandro Winograd for making available unpublished information. Special thanks to all those whom one way or another collaborated in the lab and in the field. To Claudia Briones, for her assistance in the initial steps of this article. And very specially to Luis
Alberto Borrero for his daily patience, his enlightening discussions and the translation of this paper. Of course, I am the only responsible of any mistakes that this article may contain. This is a brief updated version of a paper that first saw the light a couple of years ago.

LANATA, J.L. The "Haush" puzzle: piecing together subsistence and settlement at the Fueguian southeast. Rev. do Museu de Arqueologia e Etnologia, São Paulo, 6: 11-32, 1996.

ABSTRACT: The Isla Grande of Tierra del Fuego - Argentina - southeast tip was archaeologically almost unknown till the middle 1980's, when systematic research began. This area was historically inhabited by the Haush, a group without a clear ethnic status. The different positions about them are summarized. The ethnographic information available and the data from the faunal resources - guanacos (Lama guanicoe), sea lions, birds and mollusks - are adjusted to postulate a subsistence and settlement model for the area - known as Peninsula Mitre. It is applied for the Rancho Donata archaeological locality, and then it is compared with other Tierra del Fuego pedestrian hunter-gatherers models. Logistical strategies for guanaco hunting seem to be more efficient yearlong. During the fall-winter semester, sea lions hunting took place within the camp range - ca. $5 \mathrm{~km}$ from the coast. The spring-summer semester base camps movement appears to be first ąssociated with bird and fish procurement and then to sea lions hunting.

UNITERMS: High latitude adaptation - Tierra del Fuego - Hunter-gatherers Faunal resource exploitation - Subsistence and settlement models.

\section{References}

BEAUVOIR, J. M.

1915 Los Selk'nam: Indígenas de la Tierra del Fuego. Buenos Aires

BELLISIO, N.R. ; LÓPEZ, R.; TORNO, A.

1979 Peces Marinos Patagónicos. Buenos Aires, Secretaría de Estado de Intereses Marítimos.

BINFORD, L.R.

1982 The archaeology of place. Journal of Anthropological Archaeology, 1: 5-31

BONDEL, C.S.

1985 Tierra del Fuego (Argentina): La Organización de su Espacio. CONICET-CADIC. Ushuaia.

BORRERO, L.A.

1985 La Economía Prehistórica de los Habitantes del Norte de la Isla Grande de Tierra del Fuego. Tesis Doctoral. Museo Etnográfico. F.F. y Letras. UBA.

1986 El proyecto arqueológico "Norte de la Isla Grande de Tierra del Fuego": Contribuciones metodológicas y principales resultados generales.
Primeras Jornadas de Arqueología de la Patagonia. Secretaria de Cultura, Rawson: 33-39.

BORRERO, L.A.; Lanata, J.L.

1988 Estrategias adaptativas representadas en los sitios de Estancia María Luisa y Cabo San Pablo. Precirculados IX Congreso Nacional de Arqueología Argentina. FFyL. UBA:166-174.

BRIDGES, E. L.

1951 Uttermost part of the Earth. Londres,Hodder \& Stoughton.

BROSSES, C. de

1756 Histoire des Navigations aus Terres Australes. Vols I. \& II, Paris.

\section{CARRARA, L.}

1952 Lobos Marinos, Pingüineras y Guaneras de la Costa del Litoral Marítimo e Islas Adyacentes de la República Argentina. La Plata, U.N.L.P.,

CASIRAGHI, $M$ Facultad de Ciencias Veterinarias.

1986 Arpones y cuñas en hueso provenientes de Ran- 
LANATA, J.L. The "Haush" puzzle: piecing together subsistence and settlement at the Fueguian southeast. Rev. do Museu de Arqueologia e Etnologia, São Paulo, 6: 11-32, 1996.

cho Donata, Península Mitre, Tierra del Fuego. PEOAF, 84: 116-131.

CHAPMAN, A

1973a Donde los mares chocan: La tierra de los antiguos Haush, Tierra del Fuego. Karukinka, 3: 5-14.

1973b El fin del mundo. Ciencia e Investigación, 29: 3-14.

1977 Economía de los Selk'nam de Tierra del Fuego. Actes du Congrès International des Américanistes Hors-série, V: 135-148.

1982 Drama and power in a hunting society: The Selk'nam of Tierra del Fuego. Cambridge, Cambridge University Press.

CHAPMAN, A.; HESTER, T.

1973 New data on the archaeology of the Haush; Tierra del Fuego. Journal de la Société des Américanistes, LXII:185- 208.

CLARK, $R$.

1986a Notas sobre la avifauna de Península Mitre. PEOAF, 84: 12-51.

1986b Aves de Tierra del Fuego y Cabo de Hornos. Guía de Campo. Buenos Aires, Ed. L.O.L.A.

COJAZZI, A.

1911 Contributi al Folk-lore e all'Etnografia dovuti alle Missioni Salesiane. Gli Indii dell'Arcipelago Fueghino. Torino.

COOK, F.A.

1900 The giant indians of Tierra del Fuego. Century Magazine, 5: 720-729.

COOPER, J.M.

1915 Fueguian and Chonoan tribal relations. 19th. International Congress of Americanistes: 445453.

1917 Analytical and critical bibliography of the tribes of Tierra del Fuego and adjacent territory. Smithsonian Institution. Bureau of American Ethnology. Bulletin 63.

DABBENE, $R$.

1904 Viaje a la Tierra del Fuego y a la Isla de los Estados. Boletín del Instituto Geográfico Argentino, XXI: 3-78

1911 Los indígenes de la Tierra del Fuego. Boletín del Instituto Geográfico Argentino, XXV: 163-226

DARWIN, C. y $247-300$

1839 Journal and remarks 1832-1836. In Narrative of the Surveying Voyages of his Majesty's Ships Adventure and Beagle, between 1826 and 1836, discribing their examination of the southern shores of South America and the Beagle circumnavigation of the globe. Volumen III. Londres, Colherns.

1958 The voyage of the Beagle. New York, Bantan Books.

FREZIER, A.F.

1716 Relation du Voyage de la Mer du Sud aux Côtes du Chili et Perou, fait pendant les années 1712, 1713 \& 1714. Paris.

FURLONG, C.W

1912 Hunting the guanaco. Outing Magazine, 61: 3-20
1915 The Haush and Ona. Primitive tribes of Tierra del Fuego. Proceedings of the 19th. International Congress of Americanists: 432-444.

1917 Tribal distribution and settlements of the fueguians, comprising nomenclature, etymology, philology and populations. The Geographical Review, III (3): 170-187.

GALLARDO, C.R.

1910 Los Onas. Buenos Aires, Cabaut y Cia.

GOMÉZ DE SARAVIA, $S$.

1986 Estudio del Intermareal de Playa Donata. MS on file Museo del Fin del Mundo. Ushuaia.

\section{GUICHÓN, R.}

1993 Antropología Biológica de Tierra del Fuego. Ph.D. Dissertation. Buenos Aires, Universidad de Buenos Aires.

GUSINDE, $M$.

1982 Los Indios de Tierra del Fuego: Los Selk'nam. CONICET - CAEA. Buenos Aires.

\section{HOLMBERG, E.A.}

1906 Viaje al interior de la Tierra del Fuego. Anales del Ministerio de Agrigultura. Sección de Inmigración, Propaganda y Geografía Tomo I, Nro. 1.

JACKSON, H. E.; POPPER, V.

1980 Coastal hunter-gatherers: The Yahgan of Tierra del Fuego. The Archaeological Correlates of Hunter-Gatherers societies: Studies from the Ethnographic Area. Michigan Discussion in Anthropology, 5(1-2): 40-61.

KING, P.P.

1839 Proceedings of the First Expedition 1826-1830. Narrative of the Surveing Vogayes of His Majesty's Ships Adventure and Beagle, between 1826 and 1836, discribing their examination of the southern shores of South America and the Beagle circumnavigation of the globe. Volumen I. Londres, $\mathrm{H}$. Colherns.

LANATA, J.L.

1986 Prospección arqueológica del Litoral septentrional. PEOAF, $84: 103-114$

1990 Human, Terrestrial and Sea Mammals at Peninsula Mitre, Tierra del Fuego. L. Davis; B.O.K. Reeves (Eds.) Hunters of the Recent Past. London, Unwin Hyman: 400-406.

1993 Estados Alterados. Procesos de formación y conjuntos faunísticos en Rancho Donata, Tierra del Fuego. Explotación de Recursos Faunísticos en Sistemas Adaptativos Americanos. J.L. Lanata (Comp.) Arqueología Contemporánea, 4. Buenos Aires: 163-176.

1995 Paisajes Arqueológicos y Propiedades del Registro en el Sudeste Fuegino. Buenos Aires, Universidad de Buenos Aires.

LANATA, J.L.; WINOGRAD, A.

1988 Gritos y Susurros: Aborígenes y Lobos Marinos en el litoral de la Tierra del Fuego. Arqueología de las Américas. $45^{\circ}$ Congreso Internacional de Americanistas, Bogotá: 227-246.

LANATA, J.L.; NAMI, H.; GUICHÓN, R.

1985 Península Mitre: Alternativas exploratorias para 
LANATA, J.L. The "Haush" puzzle: piecing together subsistence and settlement at the Fueguian southeast. Rev. do Museu de Arqueologia e Etnologia, São Paulo, 6: 11-32, 1996.

un problema arqueológico. Presented at the VIII Congreso Nacional de Arqueología Argentina. Concordia, Libro de Resúmenes. Concordia: 9.

1988 Armando el Rompecabezas: Nuevos datos para Península Mitre. Presented at the $I X$ Congreso Nacional de Arqueología Argentina. Buenos Aires, Libro de Resúmenes. Buenos Aires, FFyL. UBA: 76

LEHMAN-NITSCHE, $\mathbf{R}$

1913 El grupo lingüístico Tshon. Revista del Museo de La Plata, XXII: 217-276.

LISTA, R.

1887 Viaje al País de los Onas. Tierra del Fuego. Buenos Aires.

LOTHROP, S.K.

1928 The indians of Tierra del Fuego. Contribution from the Museum of the American Indian, 10.

MARTINEZ CROVETTO, $R$.

1968 Nombres de plantas y sus utilidades según los indios onas de Tierra del Fuego. Etnobiológica, 3: $1-20$

1978 Los indios onas y las plantas. Karukinka, 23: 1925.

MERINO, M.

1988 Estructura social, area de acción y parámetros poblacionales de guanaco (Lama guanicoe Muller 1776) del área comprendida entre Bahía Policarpo y Bahía Thetis, Tierra del Fuego, Argentina. MS on file, Museo Territorial, Ushuaia.

MOORE, D.M.

1983 Flora of Tierra del Fuego. A. Nelson. Botanical Garden. Londres \& Missouri.

MOORE, K.

1980 Archaeological correlates of the Ona: Huntergatherers of the sub-antartic. The Archaeological Correlates of hunter-Gatherers Societies: Studies from the Ethnographic Area. Michigan Discussion in Anthropology, 5(1-2): 62-77.

MUÑOZ, A.S

1994 Arqueofaunas de la Costa Atlantica Fueguina. Marcas Naturales y Huellas Culturales. Tesis de Licenciatura. Buenos Aires, Facultad de Filosofía y Letras. Universidad de Buenos Aires.

NAMI, H.G.

1986 Observaciones preliminares sobre la tipología y tecnología de los artefactos liticos procedentes del sitio Rancho Donata. PEOAF, 84. Museo Territorial. Ushuaia: 134-146.

1992 Noticia sobre la existencia de técnica 'Levallois' en Península Mitre, extremo sudoriental de Tierra del Fuego. Anales del Instituto de la Patagonia Cs. Hu., 21: 73-80

NODAL, B.G.; GONZÁLO de

1621 Relación del Viaje que por orden de su Majestad y de acuerdo de El Real Consejo de Indias hicieron los capitanes Bartolomé García de Nodal y Gonzálo de Nodal, hermanos, naturales de Pontevedra, al descubrimiento del Estrecho Nuevo de San Vicente, que hoy es nombrado de Maire y Reconocimiento del de Magallanes. Cádiz, Real Marina.

ORQUERA, L.A., SALAS, A.; PIANA, E.; TAPIA, A.

1977 Lancha Packewaia. Arqueología de los Canales Fueguinos. Buenos Aires, Ed. Huemul.

OSBRON, A.J.

1977 Strandloopers, mermaids and other fairy tales: Ecological determinants of marine utilization The peruvian case. L.Binford (Ed.) For Theory Building in Archaeology. New York, Academic Press: 157-206

PARKINSON, $S$.

1784 A Journal of a Vogaye to the South Seas, in H.M.S. the Endeavour. Second edition. (First edition 1773). Londres.

PURÍSIMA CONCEPCIÓN

n.d. Diario del Navegación y acaecimientos del navio nombrado la Purísima Concepción (alias Los Pasages) en su viaje desde el Puerto de Cádiz a los Mares del Sur, que dió principio el 12 de Enero de 1764. Xeroxcopy on files at the Museo Territorial, Ushuaia.

RATTO, N.R.

1991 Análisis funcional de las puntas de proyectil líticas de sitios del sudeste de la Isla Grande de Tierra del Fuego. Arqueología, 1: 151-178.

1993 What and how did they hunt?: Methodological essay to approach the question of prehistoric hunting techniques. Explotación de Recursos Faunisticos en Sistemas Adaptativos Americanos. J.L. Lanata (Comp.) Arqueología Contemporánea, 4. Buenos Aires, Edición Especial: 135-148.

SAVANTI, F

1994 Las Aves en la Dieta de los Cazadores-Recolectores Terrestres de la Costa Fueguina. Temas de Arqueología. PREP-CONICET. Buenos Aires.

SEGERS, $P$.

1891 Hábitos y Costumbres de los Indios Aonas. Boletín del Instituto Geográfico Argentino, XII (5 6): $56-82$

SEGURA, J.

1973 Don Manuel Lefrant en la bahía fueguina del Buen Suceso. Karukinka, 4: 3-8

SKOTTSBERG, $\mathrm{C}$

1911 The wilds of Patagponia. A narrative of the swedish expedition to Patagonia, Tierra de Fuego and the Falkland Islands in 1907-1909. Londres.

1913 Observations on the native of the Patagonian channel region. American Anthropologist, 15: 578616.

SPEGAZZINI,C

1882 Costumbres de los habitantes de la Tierra del Fuego. Anales de la Sociedad Científica Argentina, XIV: 159-181.

STUART, D.

1977 Seasonal phases in Ona subsistence, territoria distribution and social organization: Implications 
LANATA, J.L. The "Haush" puzzle: piecing together subsistence and settlement at the Fueguian southeast. Rev. do Museu de Arqueologia e Etnologia, São Paulo, 6: 11-32, 1996.

for the archaeological record. L. Binford (Ed.) For Theory Building in Archaeology. New York, Academic Press: 251-286.

1983 Subsistencia Yahgan y patrones de movilidad en canoas. Arqueología Contemporánea, 1: 20-27.

VIDAL, H.J.

1985 Los conchales de Bahía Valentín. Tesis de Licenciatura. Museo Etnográfico. F. Filosofía y Letras. UBA.

1986 Prospección arqueológica del litoral septentrional. PEOAF, 84. Museo Territorial. Ushuaia: 199-240.

1987 Primeros lineamientos para una arqueología etnográfica de la Península Mitre. Primeras Jornadas de Arqueología de la Patagonia. Rawson, Secretaría de Cultura: 303-309.

1988 Bahía Valentín: 6.000 años de ocupaciones humanas en el oriente fueguino. IX Congreso $\mathrm{Na}$ - cional de Arqueología Argentina. Libro de Resúmenes, Buenos Aires: 77.

WILKES, C.

1845 Narrative of the United States Exploring Expedition During the Year 1838, 1839, 1849, 1841, 1852. 5 Vols. Philadelphia.

WINOGRAD, A.

1986 Presencia de Pinnípedos en el litoral septentrional. $P E O A F$, 84. Ushuaia, Museo Territorial: 69-101.

YESNER, D.R.

1980 Maritime hunter-gatherers: Ecology and prehistory. Current Anthropology, 21: 727-750.

YESNER, D.; FIGUERERO, M.J.; GUICHÓN, R.; BORRERO, L.A.

1991 Análisis de isótopos estables en esqueletos humanos: confirmación de patrones de subsistencia etnográfica para Tierra del Fuego. Shincal, 3(2): 182-190.

Recebido para publicação em 26 de agosto de 1996. 